\title{
Middle Dutch back vowels in rhymes
}

\author{
Johanneke Sytsema • Janet Grijzenhout • \\ Aditi Lahiri
}

Received: 4 May 2012 / Accepted: 21 August 2013 /Published online: 6 September 2014

(C) Springer Science+Business Media Dordrecht 2014

\begin{abstract}
Dutch underwent many changes in its vowel system in the course of its history. One way of exploring the phonology of the vocalic system at an earlier period of the language is to examine rhymes. The rhyming verse which is used in the moral didactic text of Ms. Marshall 29 offered an excellent opportunity to not only establish the differences between Modern and Middle Dutch, but also to trace any variation in the transition period from early to late Middle Dutch. We focused on rounded vowels, which were indicated by

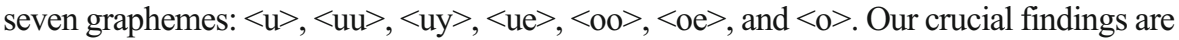
the following: (i) descendants of Proto Germanic (PGmc) */au/ and */o:/ never rhyme with each other, although they could be spelt in an identical fashion and are pronounced the same in Modern Dutch, which leads us to conclude that the Middle Dutch vowel qualities were different; (ii) descendants of PGmc */u/ became / $/$, but when this vowel is lengthened in open syllables, it never rhymes with vowels derived from PGmc */au/, although they do in Modern Dutch; (iii) although $<\mathrm{e}>$ added to a vowel can mark length, in a small subset it must have indicated fronting.
\end{abstract}

Keywords Middle Dutch · Vowel change · Back rounded vowels · Fronting · Palatalisation

\section{Introduction}

Rhymes belonging to an earlier period of a language offer an excellent means of establishing the historical development of the phonological system. Spelling

J. Sytsema $(\bowtie) \cdot$ A. Lahiri

Faculty of Linguistics, University of Oxford, Oxford, UK

e-mail: johanneke.sytsema@ling-phil.ox.ac.uk
A. Lahiri
e-mail: aditi.lahiri@ling-phil.ox.ac.uk
J. Grijzenhout
Department of Linguistics, University of Konstanz, Konstanz, Germany
e-mail: janet.grijzenhout@uni-konstanz.de 
conventions and poetic license can be misleading; nevertheless, to extrapolate away from spelling variations, one could argue that words which rhyme have identical vowel quality and quantity while lack of rhymes with certain vocalic graphemes may suggest that these vowels are different. This paper considers what rhyme can tell us about the Dutch vowel system in the medieval period. Our interest is focused particularly on round vowels which underwent fronting (umlaut), raising, diphthongization, as well as lengthening when compared to the Proto Germanic (PGmc) system. Although there are individual descriptions of these phenomena, no comprehensive study exists that traces the development of all the rounded vowels during the medieval period. Nor is there a synchronic phonological grammar of this period. Furthermore, controversy still rages around the precise timing as well as context of lengthening and fronting. Our goal is to discern as accurately as possible the phonological system of the back round vowels of Middle Dutch, deduce how they developed from Proto Germanic and establish to what extent these are similar to or different from Modern Dutch. Our data sheds new light on the diachronic development from Proto Germanic to Modern Dutch, while providing a synchronic analysis of 14th century Middle Dutch vowels.

Traditional grammars refer to 'Old Dutch' as the period starting in the fifth century and lasting until the middle of the twelfth century. It is generally accepted that the Middle Dutch period started around 1150 AD, although the first Middle Dutch literary texts are not recorded until around 1200 AD. More texts are recorded around $1250 \mathrm{AD}$, including Ferguut, Karel ende Elegast, Lutgart, and Jacob van Maerlant's Der natueren bloeme. The Middle Dutch period continued until around $1550 \mathrm{AD}$, but is often split into an early (1150$1350)$ and a late period (1350-1550). The manuscript we have chosen was composed in the period of transition from Early to Late Middle Dutch, the second half of the 14 th century. ${ }^{1}$

The moral didactic text of the manuscript (Ms.) Marshall 29, written in rhymes, gives us unique insight into the development of the vowel system in the second half of the 14th century in the dialect of Brabant. The Ms. Marshall 29 is kept in the Bodleian Library at the University of Oxford. In all probability, Thomas Marshall, rector of Lincoln College in Oxford, acquired the manuscript while he was in the Netherlands as a vicar in the years 1647-1672 (see Deschamps 1972:119). The parchment manuscript is complete, comprising 102 folios in 13 gatherings. According to Kienhorst (2005:799), the text in littera textualis in two columns of 49 lines each, is written by one hand. However, we have discovered that there are two barely distinguishable hands $\left(\mathrm{f} .1^{\mathrm{r}}-68^{\mathrm{r}}\right.$ and $\left.68^{\mathrm{v}}-102^{\mathrm{v}}\right) .^{2}$ Carefully comparing line initial capitals, we find that various letters including $\mathrm{D}, \mathrm{H}, \mathrm{L}$ and $\mathrm{W}$ are differently shaped from f. $68^{\mathrm{v}}$ onwards. This change is sudden and takes place in the middle of Book III and each individual hand is consistent. Ms. Marshall 29 contains the following four books:

\footnotetext{
${ }^{1}$ Kienhorst dates the codex around 1375 and states that it was compiled as a codicological unity (Kienhorst 2005, 799).

${ }^{2} \mathrm{f}=$ folio, ${ }^{\mathrm{r}}=$ recto, ${ }^{\mathrm{v}}=$ verso.
} 
I Mellibeus het boec van troeste (by Jan van Boendale) is a didactic poem from Latin Liber consolationis et consilii by Albertanus van Brescia and completed in 1342. It is written as a dialogue between Mellibeus and his wife Prudencia about a moral way of life.

II Jans Teesteye (by Jan van Boendale) is a dialogue between Jan (van Boendale) and his friend Wouter about moral decline in society.

III Boec van der wraken (by Jan van Boendale) is concerned about God's wrath in history.

IV This book contains various texts.

(i) In Dit es van Maskeroen (by Van Velthem, cf. Besamusca, Sleiderink \& Warnar 2009: 12-13) Maskeroen, representing the devil, tries to resist God's plan to save humanity but Mary intervenes.

(ii) In Van den coninc Saladijn ende van Hughen van Tabaryen (by Hein van Aken), from French Ordène de chevalerie, by Hues de Tabarie, the captured crusader Hughe van Tabaryen appears in front of King Saladin and makes the king a knight, thus securing his release.

(iii)Die tien plaghen ende die 10 gheboden and Dit is noch van salladine, concerning King Saladin's death.

The authors of the various texts hail from Brabant. Jan van Boendale (12791351) came from Antwerp as we see from Jans Teesteye. ${ }^{3}$ Furthermore, in Boec der wraken, the author refers to Antwerp as his base; e.g., Ic hoorde tantwerpen daer ic sat 'I heard in Antwerp where I sat'. 4 His contemporary, Lodewijk van Velthem, worked in Zichem before being appointed in VeltemBeisem, ${ }^{5}$ and the author of Saladijn, Hein van Aken ${ }^{6}$ (ca.1250-1330), was born in Brussels. ${ }^{7}$ Thus, one can assume that the original dialect was that of Brabant, although we must keep in mind that those who copied the manuscript later may have introduced their own dialect forms. This is a possibility particularly when there are inconsistencies in word forms. We turn to this when we discuss multiple spellings. ${ }^{8}$

\footnotetext{
${ }^{3}$ Book II, paragraph 2.1:

Alle die ghene die dit werc Sien lesen ende horen Die gruetic Jan gheheten clerc Vander vueren gheboren Boendale heetmen mi daer Ende wone tandwerpen nv Daer ic ghescreuen hebbe menech jaer Der scepenen brieue dat seggic $\mathrm{v}$

'All those who will see, read and hear this work I, known as Jan the clerk, salute born in Vueren where one calls me Boendale and living in Antwerp right now where I have written for many years letters to the councillors, this I tell you.'
}

\footnotetext{
${ }^{4}$ Book III, paragraph 3.51

${ }^{5}$ Besamusca et al. 2009, 15

${ }^{6}$ Book IV, paragraph 4.02 :
}

Dit heeft ghedicht te loue ende teren Allen riddren . heyne van aken

'This poem has been written to the praise and honour of all knights: Heyne van Aken'.

${ }^{7}$ Kestemont (2013). Het gewicht van de auteur; Stylometrische auteursherkenning in de Middelnederlandse literatuur.

${ }^{8}$ Cf. Berg, E. van den. 1986. Over het lokaliseren van Middelnederlandse rijmteksten. Verslagen en mededelingen van de Koninklijke Academie voor Nederlandse taal-en letterkunde (nieuwe reeks): 305-322. 
The 14th century is especially interesting since it is the transitional stage from Early Middle Dutch to Late Middle Dutch during which some vowel changes were near completion, whereas others were still in progress, or had just begun to take effect. We selected and transcribed 2,100 lines with a total of 11,000 words. ${ }^{9}$ Equal numbers of lines were selected from each of the four books. In order to establish the quality of Middle Dutch rounded vowels, we selected all rhyme pairs with the vowel graphemes $\langle\mathrm{u}>,<\mathrm{uu}\rangle,<$ uy $>,<$ ue $>$, $<_{\mathrm{oe}}>,<_{\mathrm{O}}>$, and $<_{\mathrm{oo}}>$. The phonetic values of the corresponding Modern Dutch graphemes are given in (1).

(1) Modern Dutch graphemes and their phonetic correspondences (Gussenhoven 1999)

\begin{tabular}{|c|c|}
\hline$\left.<\mathrm{u}\rangle_{\text {open syll }},<\mathrm{uu}\right\rangle_{\text {closed syll }}$ & [y] \\
\hline$<\mathrm{u}\rangle_{\text {closed syll }}$ & {$[\mathrm{Y}]$} \\
\hline$<$ ui $>$ & [œy] \\
\hline$<$ oe $>$ & {$[\mathrm{u}] /[\mathrm{u}:]^{10}$} \\
\hline$<0>_{\text {open syll }},<\mathrm{OOO}>_{\text {closed syll }}$ & [o:] \\
\hline$<0\rangle_{\text {closed syll }}$ & [०] \\
\hline
\end{tabular}

As we shall see, the Middle Dutch features of these vowels were not always the same. We are dependent on orthography, but the rhymes enable us to determine quite precisely the phonetic values of the vowels and how they changed. For instance, we will argue that the grapheme $<$ oe $>$, which corresponds to [u:] in Modern Dutch, has different values in Middle Dutch. Sometimes the $<\mathrm{e}>$ grapheme in conjunction with a rounded vowel has been used in Germanic languages to indicate fronting of a vowel, but that is not always the case in the development of the Dutch vowels. The grapheme $<\mathrm{e}>$ when attached to another

\footnotetext{
${ }^{9}$ Johanneke Sytsema is in the process of transcribing the entire manuscript to produce an edited text, which will be made available in an e-publication. The manuscript as a whole contains 20,400 lines (Book I=4400 lines, Book $\mathrm{II}=4800$ lines, Book $\mathrm{III}=6600$ lines, Book $\mathrm{IV}=4600$ lines).

${ }^{10} \mathrm{It}$ is often assumed that long /u:/ was shortened in all contexts except before /r/ (e.g., Trommelen 1983). For the purpose of this paper, it suffices to say that Modern Dutch does not maintain a length contrast for this vowel and we have consistently indicated the Dutch vowel as long.
} 
vowel could also indicate vowel length. Copyists were faced with more phonemes than graphemes, and used the letters intelligently to capture all the contrastive sounds in their language. Our goal is to discern as accurately as possible what these phonemes were.

Rhyme is consistently used throughout the manuscript, which enables us to compare vowels in rhyming words. The rhyme scheme is either 'aabb' (see 2) or 'abab' (see 3). ${ }^{11}$ The examples in (2) and (3) have the same spelling in Middle and Modern Dutch. The corresponding Modern Dutch pronunciations are given as well.

(2) $\mathrm{MNL}^{12}<\mathrm{oe}>=$ Dutch $[\mathrm{u}:] /[\mathrm{u}]$

\begin{tabular}{|l|c|c|}
\hline & MNL & $\begin{array}{c}\text { Modern } \\
\text { Dutch }\end{array}$ \\
\hline 0026 & Voert suldi v doen hoeden & {$[$ hu:dən] } \\
\hline 0027 & Ghetruwen vrienden ende goeden & {$[$ xu:dən] } \\
\hline 0028 & Die ghi in allen stonden & [stəndən] \\
\hline 0029 & Goet ende ghetruwe hebt vonden & [vəndən] \\
\hline
\end{tabular}

(3) $\mathrm{MNL}<\mathrm{oo}>=$ Dutch [o:]

\begin{tabular}{|l|c|c|}
\hline 1739 & Ende dat ghi recht al totter doot & {$[\mathrm{do}: \mathrm{t}]$} \\
\hline 1741 & Ende wer die heilighe kerke heeft noot & {$[\mathrm{no:t}]$} \\
\hline
\end{tabular}

However, not all rhymes are so consistent. Compared to Modern Dutch, we find some anomalies in the rhyming words with high and mid back vowels. The

\footnotetext{
${ }^{11}$ Line numbers refer to the lines in our present corpus; when the transcription is complete, the line numbering will have to be different. However, the present transcribed corpus will be available on our web page very soon. Following the tradition of diplomatic editions, we use italics for resolved abbreviations in the examples.

${ }^{12}$ We use the following abbreviations: Dutch=Modern Dutch, MNL (Middelnederlands)=Middle Dutch, PGmc=Proto Germanic, $\mathrm{OE}=$ Old English, $\mathrm{OHG}=$ Old High German, OFR=Old Frisian .
} 
rhyming pairs may not match in spelling, and may or may not match in rhyme in Modern Dutch. Sometimes the vowel that has a high quality in Modern Dutch (e.g., toe /tu/ 'to') is found in a rhyme pair with a vowel that has a mid quality today (e.g., also /also:/ 'so'). The word also is still in use (alzo in Modern Dutch) but viewed as being rather old fashioned.

(4) Variable spelling in MNL, different quality in Dutch

\begin{tabular}{|l|c|c|}
\hline 0121 & Op sine starke huse also & [alzo: $]$ \\
\hline 0122 & Ende dat bringt houerde al toe & {$[\mathrm{tu}:]$} \\
\hline
\end{tabular}

Moreover, we find rhyme pairs where both vowels have the same quality today, but where the copyist used different spellings in MNL:

(5) Variable spelling in MNL, same quality in Dutch ${ }^{13}$

\begin{tabular}{|c|c|c|c|}
\hline & MNL & Dutch & \\
\hline 1239 & Daer si deden iammer groet & {$[$ xro:t] } & <groot> \\
& & & 'big; much' \\
\hline 1240 & Menighe kerstine sloeghen si doot & {$[$ do:t $]$} & $<$ dood $>$ 'dead' \\
\hline
\end{tabular}

Thus, the Modern Dutch high or mid back vowels /u:/ and /o:/ could both be written with the graphemes $<$ oe $>$ in the manuscript, and sometimes Middle Dutch words with orthographic $<_{\mathrm{oe}}>,<_{\mathrm{O}}>$ and $<_{\mathrm{OO}}>$ occur as rhyme pairs. What is interesting is that the correspondences, even within Middle Dutch, are not entirely consistent. We will demonstrate that despite the spelling alternations, some vowels that occur in rhyme pairs with these spellings are clear cases of Middle Dutch /u:/, whereas others are clear cases of Middle Dutch /o:/. Some vowels in rhymes, however, are not clearly identifiable, because they had either undergone other changes, or were not yet affected by phonological processes that occurred later in the history of Dutch.

\footnotetext{
${ }^{13}$ Here and below, we will provide the IPA transcription and glosses for the rhyming words only.
} 
Not just rhymes but the lack of rhymes are informative. Of particular interest is the variability between the Proto Germanic source, Modern Dutch vowel quality and the lack of rhyme in Middle Dutch vowels which descended from $\mathrm{PGmc} * / \mathrm{u} /$ and $* / \mathrm{au} /$. We will argue that though the descendants of these Proto Germanic vowels are identically pronounced in Modern Dutch (e.g., gode [go:də] from PGmc*/u/ vs. rode [ro:də] from PGmc */au/), these must have had different vowel quality in Middle Dutch since they never rhyme.

The structure of the paper is as follows. Section 2 considers rhyme pairs where $<$ oe $>$ or $<$ ue $>$ are used for vowels that correspond to Modern Dutch /u:/, while in Section 3, we turn to those vowels which are now pronounced as /au/. Sections 4 and 5 address variation across syllable types and vowel length focusing on mid rounded vowels. Throughout our discussion we draw attention to comparative evidence across other Germanic languages and trace the history of the Middle Dutch vowels back to Proto Germanic. In conclusion, we will argue that although there have been a number of changes since Proto Germanic times, the Middle Dutch vowel system has been largely retained in the present system.

\section{Rhyme pairs with MNL <oe> corresponding to Dutch [u:] in Marshall 29}

As we have seen in (2), rhyme pairs spelt with $<$ oe $>$ often, though not always, correspond to Modern Dutch /u:/.

(6) $\mathrm{MNL}<$ oe $>=$ Dutch [u:]

\begin{tabular}{|l|l|l|l|}
\hline 0062 & Goede hoede es altoes goet & {$[\mathrm{xu}: \mathrm{t}]$} & $<$ goed $>$ 'good' \\
\hline 0063 & Ende hi es wijs diese doet & {$[$ du:t $]$} & $<$ doet $>$ 'do-3'sg.' \\
\hline
\end{tabular}

We can trace the origin of these vowels to PGmc */o:/, which has been raised to /u:/ in present day Dutch and spelt <oe>, e.g., broeder 'brother', boek 'book'. ${ }^{14}$ However, in some Flemish texts from the 14th century onwards, PGmc */o:/ is raised to /u:/ (sometimes written as $<\mathrm{ou}>$ ) only before a labial or a velar (e.g., roupen 'to call' and bouc 'book'; Van Bree 1987:129-131). ${ }^{15}$

\footnotetext{
${ }^{14}$ The PGmc */o:/ was fronted in the other Germanic languages in the context of /i/, /j/; e.g., OE blöd, blēdan; brōpor, brēper. Whether umlaut did or did not occur in Dutch is a controversial topic which is not relevant here. However, we do find some remnants of /e/ for PGmc */o:/ in these contexts, e.g., MNL brueder, but Dutch broeder. We return to this later.

${ }^{15}$ This spelling convention is probably due to the influence of copyists who knew French, where $<$ ou $>$ represented the sound $/ \mathrm{u}: /$.
} 
There is little consensus in the literature about when the change from */o:/ to /u:/ was completed in the Brabant dialect. Our goal is to establish the quality of the vowel in this dialect at the time when the manuscript was written and to determine whether raising of */o:/ to /u:/ had already been completed. In order to investigate the quality of this phoneme in the second half of the 14th century, we will first examine the six most frequently occurring words which had long */o:/ in PGmc. Since relevant Old Dutch data is lacking, we give the corresponding words in Old English for comparison.

(7) Correspondences of $\mathrm{MNL}<\mathrm{oe}>$ to $\mathrm{PGmc} * / \mathrm{o}: /$ and $\mathrm{OE}<\overline{\mathrm{o}}>$

\begin{tabular}{|c|c|c|c|c|c|}
\hline Marshall 29 & Occurrences & Dutch /u:/ & PGmc & $\begin{array}{c}\text { Old } \\
\text { English }\end{array}$ & Gloss \\
\hline bloet & 10 & bloed & $* b l \bar{o} d a$ & $b l \bar{d} d$ & 'blood' \\
\hline boec & 10 & boek & $* b \bar{o} k$ & $b \bar{o} c$ & 'book' \\
\hline doen & 23 & doen & $* d \bar{o} n^{16}$ & $d \bar{o} n$ & 'to do' \\
\hline goet/goede & 50 & goed & $* g \bar{o} d a$ & $g \bar{o} d$ & 'good' \\
\hline hoe & 35 & hoe & $* h w \bar{o}$ & $h \bar{u}$ & 'how' \\
\hline moet & 27 & moeten & $* m \bar{o} t-$ & $m \bar{o} t-$ & 'must' \\
\hline
\end{tabular}

All the examples in (7) are consistently spelt with $<$ oe $>$ and when they occur in rhyming couplets, their corresponding rhymes are spelt in the same way.

The word bloet/bloede (Dutch /blu:d/) 'blood' is found eight times in our corpus (lines 0060, 0851, 0987, 0992, 1009, 1265, 2033, and 2042), bloedechtich 'blood-like' occurs once in line 1004 and bloedigher 'more bloody' in line 2034. The word boec 'book' (lines 0220, 0248, 0616, 0631, 0923), is also found as $d$ boec 'the book' (line 0648) and as boeke (line 0051). Its diminutive forms boecksen and boekelkijn are found in lines 1208 and 1964 and the plural form boeken is found in line 0806. Since the word is always used at the beginning or the middle of a line, we could not find a rhyming pair for boec.

The adjectival and adverbial stem goet/goede (underlying /gu:d/) 'good' occurs 50 times in our corpus. The word hoe 'how' occurs in 35 instances. The verbal stem moet (from underlying /mu:t/ 'must') is attested 27 times in our corpus. Some examples of rhymes with $<\mathrm{oe}>$ are given in (2), (6), and (8).

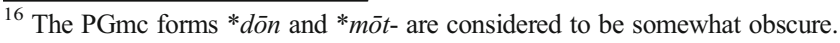


(8) $\mathrm{MNL}<\mathrm{oe}>=$ Dutch [u:]

\begin{tabular}{|l|l|c|c|}
\hline 0511 & Vanden eyghendome yrst toe & {$[\mathrm{tu}:]$} & $<$ toe $>$ 'to' \\
\hline 0512 & Ende alse een peert of een coe & {$[\mathrm{ku}:]$} & $<$ koe $>$ 'cow' \\
\hline
\end{tabular}

\begin{tabular}{|l|l|l|l|}
\hline 2038 & Nv hoort waerde mensche goet & {$[\mathrm{xu}: \mathrm{t}]$} & <goed > 'good; well' \\
\hline 2039 & Ende merct aen des waters vloet & [vlu:t] & <vloed > 'flood' \\
\hline
\end{tabular}

Our corpus includes 29 words (241 tokens) that can all be traced back to PGmc words with */o:/ (cf. Philippa et al. 2009; Middelnederlandsch Woordenboek 1885; Oxford English Dictionary 2009; Skeat 1882; Amos et al. 1986). These words are consistently spelt with $<$ oe $>$ and generally rhyme with words also spelt in the same way. The data allow us to conclude that all words consistently spelt with $<_{0 e}>$ in the manuscript (e.g., bloet 'blood', boec 'book', coe 'cow', doen 'to do', goet 'good', hoe 'how', moet 'must') are descendants from PGmc words with */o:/, and are pronounced as /u:/ as is the case in their Modern Dutch descendants. In Marshall 29, the vowel that corresponds to PGmc */o:/ is never orthographically written with $<_{0}>$ (in open syllables) nor with $<_{00}>$ (in closed syllables). Furthermore, the following consonantal context plays no role - neither voicing nor place of articulation causes any alternation. Thus, our first conclusion is that PGmc */o:/ was already raised and pronounced as /u:/ in the Brabant dialect at the time the manuscript was composed and has remained as such. There is no obvious later period where this change could have taken place.

\subsection{Alternations between MNL $<$ oe $>$ and $<$ ue $>$}

There are, however, a few words descended from PGmc */o:/ which are sometimes written with $<$ ue $>$ rather than $<$ oe $>$, although their present counterparts are always written with $<\mathrm{oe}>$ and pronounced as $/ \mathrm{u}: /$. This suggests that in some instances the Brabant vowel quality was not identical to present day Dutch, nor was it the same as PGmc */o:/. This has also been noted by Van Bree (1987:130) who states that some words show alternations in the spelling between $<$ oe $>$ and $<$ ue $>$ in the Brabant dialect. Marshall 29 contains relatively few stems which alternate in spelling between $<$ oe $>$ and $<$ ue $>$; all are listed below. ${ }^{17}$

\footnotetext{
${ }^{17}$ Blanks indicate that the form in question does not occur in our material. The form *groete meaning 'to greet', for example, is not attested though this spelling has been found elsewhere.
} 
(9) Words originating from PGmc */o:/ which alternate in spelling between $<\mathrm{oe}>$ and $<$ ue $>$ in Marshall 29.

\begin{tabular}{|c|c|c|}
\hline & spelling with $<$ oe $>$ & spelling with $<$ ue $>$ \\
\hline a. & bedroeft (1007) 'sad' & druefheyt (0259) 'sadness' \\
\hline b. & broeder (0698) 'brother' & $\begin{array}{l}\text { brueder (1212) 'brother' } \\
\text { ghebruedere (0526) 'brothers' }\end{array}$ \\
\hline c. & $\begin{array}{c}\text { hoede }(0013,0018,0040,0042, \\
\text { 0062, 0177) '(on his) guard' } \\
\text { hoeden }(0026,0031,0035,0039) \\
\text { 'to heed' } \\
\text { verhoedt (0023) 'forbid' }\end{array}$ & $\begin{array}{c}\text { huede (0299) 'guard' (1 }{ }^{\text {st }} \text { sg.) } \\
\text { behuedt (2095) 'watch over' (past } \\
\text { part.) }\end{array}$ \\
\hline d. & & $\begin{array}{c}\text { gruetic }(0203,0209,0620) \text { 'I greet' } \\
\text { gruete }(1648) \text { 'greeting' }\end{array}$ \\
\hline e. & $\begin{array}{c}\text { ghemoet }(0591) \text { 'heart, soul' } \\
\text { saechtmoedich }(0872,1057) \text { 'gentle, } \\
\text { meek' } \\
\text { oetmoed/oetmoede } \\
(0152,1715,1757,1837) \text { 'meekness, } \\
\text { humility' }\end{array}$ & ghemuede (2068) 'heart, soul' \\
\hline f. & soetste (0322) 'sweetest' & suete $(2059,2071)$ 'sweet' \\
\hline g. & $\begin{array}{c}\text { vroech }(0275,0320,0395,0527) \\
\text { 'early' }\end{array}$ & vruech (1738) 'early' \\
\hline
\end{tabular}

There are two possible explanations for this variation. The first hypothesis is that this handful of words reflects a dialect variation, where the copyist differs from the original. ${ }^{18}$ There are, however, two problems with this hypothesis. First, as we noted, the manuscript is written by two hands and these form-variants are found throughout the text. Although some forms only appear either in the first or the second half (e.g., vruech is found only in the second half, vroech only in the first), it is not the case that the variants are restricted to any particular part of the text. Both $<_{\mathrm{ue}}>$ and $<_{\mathrm{oe}}>$ appear in both halves. The second problem, as we elaborate below, is that the historical phonological context of these words is too consistent to ignore. To examine the original contexts more closely, we compared the cognates of these words with three other PGmc languages, Old High German, Old English, and Old Frisian. The next table summarizes our findings.

$\overline{18}$ cf. van den Berg \& Berteloot (1991: 238-273) and van den Berg \& Berteloot (1994: 34-54). 
(10) $\mathrm{MNL}<$ oe $>\sim<$ ue $>$ alternations from PGmc */o:/ and cognates

\begin{tabular}{|c|c|c|c|c|}
\hline Marshall $29<$ oe $>\&<$ ue $>$ & PGmc $\bar{o}$ & $\mathrm{OHG}$ & $\mathrm{OE}$ & OFR \\
\hline $\begin{array}{c}<\text { bedroeft }>(<\text { droef }>) \\
<\text { druefheyt }>\end{array}$ & $* d r o ̄ b i-$ & truobi & $d r o ̄ f$ & - \\
\hline $\begin{array}{c}<\text { broeder }> \\
<\text { brueder }>,<\text { ghebruedere }>\end{array}$ & *brōper & bruoder & $\begin{array}{c}\text { brōpor } \\
\text { brēper - DAT SG }\end{array}$ & brother \\
\hline$<$ ghemoet $>,<$ ghemuede $>$ & $* m \bar{o} d a-$ & - muati & $-m \bar{e} d e$ & $m \overline{o d}$ \\
\hline$<$ groet $>,<$ gruete $>$ & *grōtjan- & gruozzan & grētan & grēta \\
\hline$<$ hoet $>,<$ huede $>$ & * hōdi- & huota & hōde, hêdan & hōde, hūde \\
\hline$<$ soet $>,<$ suete $>$ & $\begin{array}{l}*_{s w o ̄ t i-} \\
*_{s w o ̄ t u-}\end{array}$ & $\begin{array}{c}\text { swuozi, } \\
\text { suozi }\end{array}$ & swète & swète \\
\hline$<$ vroech $>,<$ vruech $>$ & $* f r \bar{o}-$ & fruo & - & - \\
\hline
\end{tabular}

These examples suggest that the vowel quality for these words, represented by $<$ oe $>$, was not identical to those that never alternated (see (6), (8)). The PGmc forms as well as the $\mathrm{OE}$ and $\mathrm{OHG}$ words suggest that the words in (9) and (10) would have been subjected to umlaut. The most common context for PGmc umlaut, or fronting of vowels, would be nominal affixes /i/ (plural or case marking), stem extensions $/ \mathrm{i} /$ and $/ \mathrm{j} /$, and the weak verb suffix $/ \mathrm{j} /$. As we can see from the OHG and $\mathrm{OE}$ examples, the stem vowel is fronted. In OE, the original unstressed affix $/ \mathrm{i} /$ is lowered to $<\mathrm{e}>$ which was probably a schwa (cf. OE brēper, swète) and earlier OE /ø/ was unrounded and became /e/ as we see in swète. Note that the front vowel affix context still occurs in OHG swuozi. OHG did not always show umlaut in writing, although Middle High German did, as does present day German (cf. Twaddell 1938). In other words like <suete>, $<$ ghemuede $>$ and $<$ huede $>$, the final written vowel $<$ e $>$ was a remnant of the original $\mathrm{PGmc} * / \mathrm{i} /$, and when this $* / \mathrm{i} /$ was present, the copyist appears to use $<$ ue $>$ to represent the middle vowel, and otherwise reverts to $<$ oe $>$. ${ }^{19}$

\footnotetext{
${ }^{19}$ A reviewer points out that unlike Marshall 29, in some Antwerp charters of this period words like goed were spelt with $<\mathrm{ue}>$. Out of four Antwerp charters we examined, two show only goed, one shows guet, and one has goed with just one alternation with guet. Note that charters from Brussels or Leuven of the same period (which are closer in dialect to our manuscript) consistently spell words like goed with <oe>.

Details of charters: Corpus Van Reenen/Mulder Charter K744r35601 (Antwerp 1356), P065p35001 (Brussels, 1350), P065p35202 (Brussels, 1352), P565r36701 (Brussels, 1367), P588r34304 (Leuven, 1343), P588r34302 (Leuven, 1343),

Compilatiecorpus Historisch Nederlands 1.0 (CHN): ambtelijke teksten 1250-1800: antwerpen_1351_1, antwerpen_1383_1, antwerpen_1391_1.
} 
The source of umlaut and palatalisation in Dutch has been of considerable interest in the Netherlands (cf. Kloeke 1927; van Reenen \& Wijnands 1993; van Reenen 2006a; Postma and van Reenen 2009; Buccini 2010). There is no doubt that present day Dutch has underlying umlauted vowels (/y/, /Y/, /ø/, /œ/) and as van Reenen and colleagues point out, the source is a combination of umlaut (triggered by [i] or [i] as in other West Germanic languages) and 'spontaneous palatalisation'. Postma \&Van Reenen (2009) argue that the complex situation that exists in the Netherlands is a consequence of gender neutralisation (a three-gender system becoming a dual gender system), arising from over-generalisation and spreading of palatalisation and umlaut. Spontaneous palatalisation largely occurs in words which could never have had an umlaut trigger while the examples in (9) are all instances where umlaut could have taken place. First, the alternations in spelling between regular $<$ oe $>$ and another digraph $<$ ue $>$ for a handful of words which descended from PGmc */o:/ were restricted to a particular context, namely following /i/ or $/ \mathrm{j} /$. Second, these words have front vowel counterparts in OE, which strongly suggests that the vowels were not /u:/. The most obvious quality would have been raised /y:/, that is, a fronted version of $/ \mathrm{u}: /$.

There are two ways to account for the historical development from PGmc to MNL. Either one could argue that the vowel */o:/ was first raised and then fronted later in MNL: PGmc */o:/ > MNL /u:/ > MNL /y:/ before /i/ (see, e.g., van Loey 1937:73); or that PGmc*/o:/ was fronted in appropriate contexts to $* / \varnothing /$ in early Dutch and both mid vowels were raised in MNL to corresponding /u:/ and /y:/.

(11) Hypothesis about fronting

\begin{tabular}{|c|c|c|c|c|c|c|}
\hline & PGmc & $\mathrm{OHG}$ & $\mathrm{OE}$ & early Dutch > & MNL & $\mathrm{D}$ \\
\hline & Umlaut & & & Raising of mid $\mathrm{Vs}$ & & \\
\hline *swōti- & $* / \mathrm{o}: />/ \varnothing: / /$ — $/ \mathrm{i} /$ & $\begin{array}{c}\text { swuozi, } \\
\text { suozi }\end{array}$ & swète & $* / \varnothing: />/ y: /<$ ue $>$ & $\begin{array}{l}<\text { soet }>/ \mathrm{u}: / \sim \\
<\text { suete }>/ \mathrm{y}: /\end{array}$ & /u:/ \\
\hline *blöda & */o:/ elsewhere & bluot & blöd & $* / \mathrm{o}: />/ \mathrm{u}: /<\mathrm{oe}>$ & <bloet> /u:/ & /u:/ \\
\hline
\end{tabular}

It is more likely that the fronting had taken place in the usual umlauting context for a handful of words, as in $\mathrm{OHG}$ and $\mathrm{OE}$, and then raised. Recall that the copyists of Marshall 29 use $<$ oe $>$ for vowels which do not have any umlaut counterparts, but use a different digraph to indicate umlaut, namely $<\mathrm{ue}>=/ \mathrm{y} /$. What is striking in our data is that words which only have $<$ oe $>$ were never in fronting contexts and those that do alternate (i.e., $<$ oe $>\sim<$ ue $>$ ) are in umlaut contexts, a possible exception being vruech. Furthermore, PGmc */u:/ (which was in all probability prounced as /y/ before $[\mathrm{r}]$ as it is nowadays) was written as $<$ ue $>$, adding to the conviction that the $<$ oe $>\sim<$ ue $>$ alternation reflects fronting (cf. Section 3 ). That is, the alternating vowels originally occurred in the context of high front vowels or glides $/ \mathrm{i} /, / \mathrm{j} /$. These occurrences are too systematic to be random. Dutch now has no alternations with umlaut, not even the minor ones that are retained in English, as in foot-feet. Clearly, the fronting 
had not affected many words and was unstable, and all alternating vowels of this type reverted back to their underlying /u:/ with no remnants of fronting. The raising was a Middle Dutch phenomenon affecting both mid rounded vowels, /o:/ and /ø:/, which became /u:/ and /y:/ respectively.

\section{Reflexes of PGmc */u:/ in MNL}

If PGmc */o:/ was raised to /u:/ in Middle Dutch, what happened to the original PGmc */u:/? It is well established that Dutch has a "palatalisation line" dividing west and east parts of the country; palatalisation has taken place in the west (van Reenen 2006b: passim). In most dialects of Old Dutch, especially those spoken in Holland, Brabant, Zeeland and Flanders, PGmc */u:/ had been fronted to /y:/ spontaneously, except before /w/ and at the end of words (van der Meer 1927:50 refers to this stage as Vormittelniederländisch 'pre-Middle Dutch'). ${ }^{20}$ Such words spelt with $\left.\langle\mathrm{u}\rangle /<\mathrm{uy}\right\rangle /<\mathrm{uu}>$ corresponded to */u:/ in PGmc and they are realized as the diphthong /øy/ in Modern Dutch. As shown in $(12)<\mathrm{u}>$ occurs in open syllables only. ${ }^{21}$

(12) Words with $<\mathrm{u}>$ in open syllables corresponding to PGmc */u:/.

\begin{tabular}{|c|c|c|c|c|}
\hline & origin & word in Marshall 29 & $\begin{array}{l}\text { Dutch } \\
\text { /œy/ }\end{array}$ & Gloss \\
\hline a. & PGmc *utan- & $\begin{array}{l}\text { buten (lines 0296, } \\
\text { 0325) }\end{array}$ & buiten & 'outside' \\
\hline b. & $\begin{array}{l}\text { Latin crux, } \\
\quad \text { crucis }\end{array}$ & $\begin{array}{l}\text { cruce (lines 0417, } \\
\text { 0798) }\end{array}$ & kruis & 'cross' \\
\hline c. & $\begin{array}{c}\text { PGmc } \\
* \text { pūsundi- }\end{array}$ & $\begin{array}{l}\text { dusent (lines 0424, } \\
\text { 0554, 0729) }\end{array}$ & duizend & 'thousand' \\
\hline d. & PGmc *hüsa & $\begin{array}{c}\text { huse (lines 0073, 0121), } \\
\text { husen (line 0094) }\end{array}$ & $\begin{array}{l}\text { huis } \\
\text { huizen }\end{array}$ & $\begin{array}{l}\text { 'house' } \\
\text { 'houses' }\end{array}$ \\
\hline e. & & $\begin{array}{c}\text { Prudentia (lines 0083, } \\
0195)\end{array}$ & Prudentia & Name \\
\hline
\end{tabular}

\footnotetext{
$\overline{{ }^{20} \text { According to van Bree }(1987: 125)}$, fronting of */u:/ to /y:/ took place in all phonological contexts in Proto Flemish.

${ }^{21}$ The vowel in question is also spelt $<\mathrm{u}>$ in open syllables in the words duuel 'devil' (line 2055) (<lat. diabolus), duuels 'devils' (lines 1577, 2026, 2048) and zuuerheit 'purity' (line 1136) (zuuer < vulg.lat. suber < lat. sobrius), where the second $<\mathrm{u}>$ represents the fricative $/ \mathrm{v} /$. In closed syllables, the single symbol $<\mathrm{u}>$ represents a short back vowel (e.g., destruxien line 0461, dunct line 0468, dus line 0470, purgatorie line 1563). In one instance in our corpus, $<\mathrm{w}>$ is used to indicate a sequence of $/ \mathrm{v} /$ followed by the short back vowel: verwllen (Modern Dutch vervullen) 'fulfill' (line 1098).
} 
We also find a single letter $\langle\mathrm{u}\rangle$ in open syllables before $\langle\mathrm{r}\rangle$ in the manuscript; examples are gheburen (lines 0117, 0118), muren (line 0118), creature (lines 0130, 2035), nature (lines 0131, 0266, 0591, 1429) and scrifturen (lines 0463, 1430). In closed syllables, we find the spelling <ue $>$, e.g., geduert in line 1519 (cf. German gedauert 'lasted') only before $<\mathrm{r}>$. This is another reason to believe that the spelling $<\mathrm{ue}>$ of words from $\mathrm{PGmc} * / \mathrm{o} /$ in fronting contexts was actually fronted.

There is variation in spelling in closed syllables before consonants other than $<r>$. In our corpus, the following orthographical representations are found in this context: $\langle\mathrm{uy}\rangle,<\mathrm{uu}\rangle$ and $<\mathrm{w}>$. We find the spelling $<\mathrm{w}>$ for PGmc */u:/ as in $w t$ 'out' in isolation as well as in compounds, e.g., wtuercoren 'chosen' (line 775). The table below presents the six word stems with PGmc */u:/ which are not spelt with $<\mathrm{w}>$. The words that occur relatively early in the manuscript tend to have $<$ uy $>$, whereas there is variation later in the text.

(13) Words with PGmc */u:/ spelt with $<u y>$ and $<u u>$ in closed syllables in Marshall 29

\begin{tabular}{|c|c|c|}
\hline spelling with <uy> & spelling with <uu> & Gloss \\
\hline huys (lines 0077, 0187, 0192) & & 'house' \\
\hline thuys (line 0147) & spruut 'at home' $\quad$ (line 1572) & 'sprout' (verb) \\
\hline spruyt (line 0907) & $\begin{array}{l}\text { oncuushede (line 1312) } \\
\text { oncuusheyt (line 1713) }\end{array}$ & $\begin{array}{c}\text { 'indecencies' } \\
\text { 'indecency' } \\
\text { cuyscheit (line 1749) }\end{array}$ \\
\hline vuylheit (line 1321) & gheuut (line 1573) & 'dirtiness' \\
\hline
\end{tabular}

The spellings $<$ uy $>$ and $<u u>$ both occur in front of the same consonants, i.e., $<\mathrm{t}>,<\mathrm{s}>$ and $<\mathrm{l}>$. The generalization seems to be that for words of which historical reconstructions have determined that they were pronounced with $* / \mathrm{u}$ :/ in PGmc and for some words which were borrowed from Latin, the spelling $\langle\mathrm{u}\rangle$ is found in the manuscript in open syllables (huse 'house' line 0121), whereas $\langle\mathrm{ue}>$ is used in closed syllables before $\langle\mathrm{r}>$ and the symbols $<\mathrm{uy}>$ and $<\mathrm{uu}>$ are used in closed syllables before other consonants (see examples in 13). According to van Loey (1937:131), it was customary during the 13th and 14th centuries to use the letter combination $<\mathrm{ue}>$ for the sound $/ \mathrm{y}: /$. If PGmc */u:/ 
had been fronted to $/ y: /$ but not diphthongized yet, we would thus expect to find the spelling $<$ ue $>$ for the words in (13), or at least rhyme pairs where the words in question rhyme with words that have a $<$ ue $>$ spelling. This is not the case. We may thus conclude that the letters $<u u>$ and $<u y>$ represented a sound different from the one written as $<u e>{ }^{22}$ We cannot elaborate further on the precise vowel quality in this paper, but we suggest that it was most probably close to a centralized vowel /øy/, which further lowered to present day /œy/. The overall 'palatalisation' of PGmc */u:/ to /øy/ was specific to Dutch. In other Gmc languages, the back vowel was fronted only in front vowel or glide contexts. This is what happened for the PGmc */o:/ in these contexts as we saw above in (10).

\section{Rhyme pairs with $<$ oe $>\sim<00>$ corresponding to Modern Dutch /o:/ from PGmc */au/}

There are a further set of words in Marshall 29 written with the digraphs $<$ oo $>$ and $<$ oe $>$ which correspond to Modern Dutch /o:/ and not /u:/. The same words can be spelt with $<$ oe $>$ or with $<00>$, e.g., groet/groot or doet doot. Examples (14)-(15) show variation between $<$ oe $>$ and $<00>$ in closed syllables.

(14) Variation in the use of $<$ oe $>$ and $<$ oo $>$ for identical words

\begin{tabular}{|l|c|c|c|}
\hline & MNL & & Modern Dutch \\
\hline 0052 & Een cleyne ader ende niet groet & {$[$ xro:t $]$} & $<$ groot $>$ 'big' \\
\hline 0053 & Bijt een grote beeste doet & {$[$ do:t $]$} & $<$ dood $>$ 'dead' \\
\hline
\end{tabular}

\begin{tabular}{|l|c|c|c|}
\hline 1735 & Her hughe dedem enen roc root & {$[$ ro:t $]$} & $<$ rood $>\quad$ 'red' \\
\hline 1737 & He sprac hi dat ghi cleyne ende groot & {$[$ xro:t $]$} & $<$ groot $>\quad$ 'big' \\
\hline
\end{tabular}

The word groet 'great' is frequently found in rhyme pairs. It occurs twice with bloet 'bare' (lines 0698/0699 and 1105/1106) and 4 times together with doet 'dead' (lines

\footnotetext{
$\overline{22}$ The fact that the spelling <ue $>$ for PGmc */u:/ is only attested before /r/ - e.g., in the word geduert 'lasted' in line 1519 - may be an indication that the vowel in question still had the quality of /y:/ before $r$-sounds, while it had undergone a change in other phonological environments. We also find the spelling $<$ ue $>$ for vowels that were not derived from PGmc */u:/; see (9).
} 
0052/0053, lines 0085/0086, lines 0708/0709 and lines 0797/0798). When spelt with $<$ oo $>$ groot rhymes with root $(1735 / 1737)$.

What is the difference between these words spelt with <oe $>$ and the others we examined in Section 2? Examining the history of the individual words, it turns out that the examples in (14) all descend from PGmc*/au/. There is one instance where both digraphs appear in a rhyming couplet which suggests that $<$ oe $>$ and $<$ oo $>$ must have had the same vowel quality.

(15) Rhymes spelt $<$ oe $>$ and $<00>$.

\begin{tabular}{|l|c|c|c|}
\hline 1239 & Daer si deden iammer groet & {$[$ xro:t $]$} & $\begin{array}{c}<\text { groot }>\text { 'big; } \\
\text { much' }\end{array}$ \\
\hline 1240 & Menighe kerstine sloeghen si doot & {$[$ do:t $]$} & $<$ dood $>$ 'dead' \\
\hline
\end{tabular}

In open syllables, $<_{0}>$ is much more frequent than $<_{0 e}>$, e.g., grote appears twenty times versus one occurrence of groete (see Appendix). This raises the following questions regarding the use of the diagraph $<$ oe $>$ :

(i) Was the digraph $<$ oe $>$ used for words descended either from PGmc */o:/ or from $\mathrm{PGmc} * / \mathrm{au} /$ because they were identical in sound?

(ii) Why would only $<\mathrm{oe}>$ descending from $\mathrm{PGmc} * / \mathrm{au} /$ rhyme with $<\mathrm{oo}>$ ?

(iii) A handful of words descended from $\mathrm{PGmc} * / \mathrm{o}$ :/ could be written with $<$ ue $>$ or $<$ oe $>$, but these never rhymed with each other. Why not?

We believe that although the words in (14a) were written with the same grapheme as those in Section 2, they were different vowel phonemes in Marshall 29. In our corpus, words with <oe> descending from PGmc */o:/ never rhyme with words spelt with $<$ oe $>$ from PGmc */au/. The latter do rhyme with $<00>$, as shown above. Also, MNL <oe> from PGmc */o:/ alternates with the umlauted form $<$ ue $>$ (see (9)) but they do not rhyme with each other, whereas MNL <oe $>$ from $\mathrm{PGmc} * / \mathrm{au} /$ alternates with $<$ oo $>$. The rhyme pair $<$ oe $>/<$ oo $>$ (see 15) suggests that $<$ oe $>$ from $\mathrm{PGmc} * / \mathrm{au} /$ rhymed with $<00>$. Since there is a strong preference for $<_{0}>$ and not $<_{0}>$ in open syllables, we assume that the vowel quality was long [o:] in $<$ groet $>$ as well as in $<$ doot $>$.

The spelling convention $<0 \mathrm{oo}>$ is used in the second half of Book III and in Book IV to represent long [o:]. Most instances of $<0 e>$ in these words occur in the first half of the document, especially in Book I (our lines 0001-0196), Book II (lines 199-613) and Book III (lines 615-1113), whereas instances with $<$ oo $>$ occur in Book III (lines 1114 1409) and Book IV (lines 1412-2103), as we can see in the examples in (16). We 
present all instances of alternating $<0 \mathrm{oe}>$ and $<00>$ in the Appendix. ${ }^{23}$ The split between the two halves of the manuscript neatly coincides with the changeover of hands, confirming that two copyists have been at work, one who copied verses 1-1113 and a second who copied the later verses.

(16) Examples of PGmc */au/ in Books 1, II, III-1114 vs. Book III later, IV

\begin{tabular}{|c|c|c|c|c|}
\hline $\begin{array}{c}\text { Book I, II, } \\
1113\end{array}$ & open syllables & $\begin{array}{c}\text { closed } \\
\text { syllables with } \\
<o e>\end{array}$ & gloss & PGmc \\
\hline & lopen (0398) & loept (0380) & 'go, walk' & *hlaupan \\
\hline & & doet (0053, & 'dead', & *dauda \\
& & $\begin{array}{c}0501,0698, \\
\text { 'death' }\end{array}$ & \\
& & 0811,0868, & & \\
\hline
\end{tabular}

\begin{tabular}{|c|c|c|c|c|}
\hline $\begin{array}{c}\text { Book III } \\
\text { 1114- \& IV }\end{array}$ & open syllables & $\begin{array}{c}\text { closed } \\
\text { syllables with } \\
<o o>\end{array}$ & gloss & PGmc \\
\cline { 2 - 5 } & & loop (1343) & 'go, walk' & *hlaupan \\
\hline & doden (1316, & doot (1240, & 'dead', \\
& $1332)$ & 'death' & *dauda \\
& & 1649,1739, & & \\
\hline
\end{tabular}

We believe that the letter $<\mathrm{e}>$ after $<_{0}>$ in these words was used as a marker of vowel length. Further confirmation comes from two instances where the copyist uses <oe> in an open syllable (e.g., groete [xro:tə] 'big' line 1299

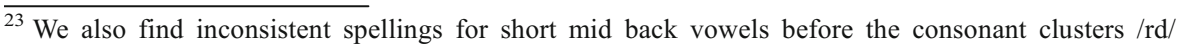
and $/ \mathrm{rt} /$. In the manuscript, this sound is represented 23 times by $<0 \mathrm{oe}, 13$ times by $<00>$ and 14 times by a single $<_{0}>$. Spellings with $<0 e>$ mostly occur in the first half of our database, e.g., in the word voert (Modern Dutch voorts 'moreover'). In the second half of the manuscript, the same words are spelt with $<00>$, e.g., voort. However, we also find instances with spellings that have one $<_{0}>$ before a consonant cluster with $<\mathrm{r}>$ : $\operatorname{vord}(\operatorname{er})$ (Modern Dutch woorden 'words'). The fact that we find spellings with $<_{0}>,<_{0}>$ and $<_{00}>$ suggests to us that lengthening before consonant clusters with $<\mathrm{r}>$ was variable in 14 th century Dutch.
} 
and hoeghe [ho:xə] 'high' line 1824) where otherwise we find $<_{0}>$ (e.g., grote line 0045 and hoghe line 1695). Examples of rhymes from different parts of the manuscript are given in (17).

(17) Middle Dutch rhyme pairs where original PGmc */au/ is spelt $<$ oe $>$ or $<$ oo $>$

Book I, II \& III (before line 1114)

\begin{tabular}{|l|l|l|l|}
\hline 0085 & Die cost waer v alte groet & [xro:t] & groot 'big' \\
\hline 0086 & Want die slote ligghen bloet & [blo:t $]$ & bloot 'bare' \\
\hline
\end{tabular}

\begin{tabular}{|l|l|l|l|}
\hline 0523 & Want christus onser alre hoeft & {$[$ ho:ft $]$} & hoofd 'head' \\
\hline 0524 & Daer tkersten volc aen gheloeft & [xəlo:ft $]$ & gelooft 'believes in' \\
\hline
\end{tabular}

Book III (after line 1114), Book IV

\begin{tabular}{|l|c|c|c|}
\hline 1265 & Dat ghi met uwen bloede root & [ro:t] & rood 'red' \\
\hline 1266 & $\begin{array}{c}\text { Den mensche droecht wt der } \\
\text { noot }\end{array}$ & [no:t] & nood 'need' \\
\hline
\end{tabular}

\begin{tabular}{|l|l|l|l|}
\hline 1342 & $\begin{array}{c}\text { Dander es persemen ende } \\
\text { voorcoop }\end{array}$ & [vo:rko:p] & $\begin{array}{c}\text { obsolete } \\
\text { ('tradesman') }\end{array}$ \\
\hline 1343 & Die ouer al heeft haren loop & [lo:p] & loop 'course' \\
\hline
\end{tabular}

\begin{tabular}{|c|c|c|c|}
\hline 1739 & Ende dat ghi recht al totter doot & [do:t] & dood 'death' \\
\hline 1741 & $\begin{array}{c}\text { Ende wer die heilighe kerke } \\
\text { heeft noot }\end{array}$ & nood 'noed' \\
\hline
\end{tabular}

The context in which $\mathrm{PGmc} * / \mathrm{au} /$ did not change into a monophthong was before the glide /w/ and at the end of words (cf. Van Bree 1987:105); hence, a 
word like schouwen [sxauwə] 'to see, to show, to display' still has a diphthong in Modern Dutch (cf. German schauen). The three instances of words with PGmc */au/ before /w/ or at the end of words are given below. ${ }^{24}$

PGmc */au/ before /w/ and word-finally is Early Dutch /au/ (spelt <ou>)

a. $\quad \operatorname{vrouwe}(\mathrm{n})<\mathrm{PGmc} *$ fraujōn- / *fraujan- 'lady' (lines 0191, 0224, 0753, 0927, 0937, 0948, 1016, 1024, 1032, 1044, 1106, 1107, 1816)

b. scouwe(n) < PGmc *skauwon 'view, examine' (lines 0631, 0655, 0790, 0928, 1003, 1820)

c. berou $<$ PGmc *-hreuwō 'remorse' (line 0750)

In sum, although the rhyming of $<_{\mathrm{oe}}>$ with $<\mathrm{oo}>$ in words from $\mathrm{PGmc} * / \mathrm{au} /$ suggested at first glance that this $<$ oe $>$ may have something in common with the descendant $<$ oe $>$ from PGmc */o:/ (Section 2), examining the rhymes and the historical scenario closely, it appears that there were two copyists and the vowel quality was different. The first part used only $<0 \mathrm{oe}>$ while $<00>$ was primarily used by the second copyist.

\section{Words which are exclusively spelt with $<0>$ : open syllable lengthening}

In Modern Dutch, some words are realized with a short vowel in closed syllables and with a long one in open syllables. This phenomenon can be observed most clearly in some singular-plural noun pairs; e.g., God [xot] is goden [xo:də] 'gods'. The assumption in the literature is that these vowels were originally short and at some point during Middle Dutch period, short vowels in stressed open syllables were lengthened (e.g., van Bree 1987:86, 91; Lahiri and Dresher 1999). The question we raise here is whether there is evidence from this manuscript that Open Syllable Lengthening (OSL) had already taken place. Generally Middle Dutch grammars assume that OSL was complete by the time of the earliest texts were written (Franck 1910: §13; Schönfeld 1947: §30; van Bree 1977: §29.4; Zonneveld 1992). Fikkert (2000), however, argues that OSL cannot convincingly be proven to have taken place in the 13th century text Lutgart only on the basis of

\footnotetext{
${ }^{24}$ Another source of the Modern Dutch diphthong /au/ is the change from a mid back vowel plus /1/ to [au]. Examples for the spelling <ou> representing the diphthong /au/ in Marshall 29:

(i) before /d/: oude, woude, soude, woudi, houde, scoude, onthoudse, soudaen

(ii) before /t/: soudt, houdt, hout, menechfout, out, outaer, scout, wouter

(iii) before /s/: vernousten

In the manuscript, only a few instances of /uld/ still appear alongside/au/, e.g., goude/guldene 'golden', soudi (line 0015)/suldi (lines 0026, 0031, 1081) 'you should'.
} 
rhyme, since the majority of rhyme pairs consist either of two originally long vowels or of two originally short vowels. That is, long vowels inherited from PGmc do not rhyme in Lutgart with those descended from short vowels in open syllables.

The data on round vowels in Marshall 29 are equally inconclusive because we do not have relevant rhyme pairs. With respect to words that have long /o:/ in Dutch open syllables and a short vowel in closed syllables, all instances in our corpus can be traced back to PGmc short */u/. Examples are the verbal stem com- 'come' (<*kuman), the nouns cont 'known' (<*kunpa-), ghebot 'command' (<*buda-.), God 'god' (<* guda-), gront 'ground' (<* grunpu-), mont 'mouth' (<*munpa-), spot 'ridicule' (<*spuppa-), stont 'hour, time' (<*stunpa-), the adjective iong 'young' ( $<*$ junga-), the pronoun ons 'us' ( $<*$ uns-) and the preposition over 'over' (<*uberi). Monomorphemic words with two consonants in the coda (including underlying /ng/) were never lengthened; cf. gront, iong. In open syllables relevant examples in the manuscript are represented by the single symbol $<\mathrm{o}>$, e.g., moghe ( $<\mathrm{PGmc} *$ mug-; line 0080), gode $(<\mathrm{PGmc}$ *guda-; line 1503) and bode ( $<\mathrm{PGmc} *$ budan; line 1504). The next table presents examples of words that correspond to open and closed syllable length alternations in Modern Dutch. As we saw in Section 4, $<_{0}>$ was used in open syllables for PGmc*/au/.

(19) Overview of words with Modern Dutch long and short variants of the mid back vowel spelt with $<_{0}>$ in Marshall 29 from PGmc */u/.

\begin{tabular}{|c|c|}
\hline $\begin{array}{c}\text { open syllables (Modern Dutch [0:]) } \\
\text { ghebode 'commands' (0781, 1906, } \\
\text { 1944) }\end{array}$ & $\begin{array}{c}\text { gebot 'command' (0139) } \\
\text { ghebot 'command' (1912) }\end{array}$ \\
\hline $\begin{array}{c}\text { gode 'God(s)' (0019, 0244, 0288, } \\
\text { 0522, 0581, 0782, 1787, 1823,1835, } \\
\begin{array}{c}\text { 1892, 1956, 2046, 2054) } \\
\text { afgode 'idol' (0782, 2062) }\end{array}\end{array}$ & $\begin{array}{c}\text { god 'God' (0003, 0004, 138, 1812, } \\
\text { gods 'God's' (1967) }\end{array}$ \\
\hline $\begin{array}{c}\text { ongodelike 'ungodly' (2047) } \\
\text { godlike 'heavenly' (1036) } \\
\text { godlijc 'heavenly' (1969) }\end{array}$ \\
\hline $\begin{array}{c}\text { moghe 'can, may' (0080), } \\
\text { moghedi 'you may' (0579) }\end{array}$ \\
\hline $\begin{array}{c}\text { orloghe 'war' (0008, 0015, 0079) } \\
\text { monten 'could' (0792) }\end{array}$ \\
\hline \hline
\end{tabular}


The lack of rhyming pairs between MNL /o:/ (from PGmc */au/, as in dode) and outputs of OSL from $\mathrm{PGmc} * / \mathrm{u} /$ like gode, could be because the vowel quality was different. Van Bree (1987:106) points out that as late as the 16th century, people differentiated these vowels and maintains that as late as early Modern Dutch, rhymes between the two vowels do not occur. As we mentioned earlier, in our 14th century manuscript we do not find such rhyme pairs either.

The only positive evidence we have is that in a few words the $<_{0}>$ is written double in a closed syllable. For instance, the word komen 'to come' (PGmc *kuman) alternates between a long vowel in open syllables and a short one in closed ones (e.g., kom 'come' $1 \mathrm{st} \mathrm{sg}$ ). In our corpus this word is spelt with $<_{0}>$ in open and closed syllables with one exception: it occurs with the spelling $<00>$ in a closed syllable in line 1839 (coomt):

(20) Words with long and short variants of the mid back vowel in Marshall 29

\begin{tabular}{|c|c|}
\hline $\begin{array}{c}\text { comen 'to come' }(0428,0471,0481, \\
\text { 0581, 0595, 0783, 1049, 1104) }\end{array}$ & comst 'arrival' (0225) \\
& comt 'comes' (0644) \\
coomt 'comes' (1839)
\end{tabular}

For us, the fact that coomt is represented with a double $<00>$ once provides an indication that vowel length in the stem of this word was probably variable.

Furthermore, an additional observation about comen 'to come' is that it rhymes with a form of (ver)doemen 'judge' twice and once it occurs in a rhyming couplet with versoemen (obsolete) which should have been $/ \mathrm{u}: /$ :

(21) Variable rhyming with comen.

\begin{tabular}{|c|c|c|c|}
\hline & MNL & $\begin{array}{c}\text { Modern Dutch } \\
\text { pronunciation }\end{array}$ & $\begin{array}{c}\text { Modern Dutch } \\
\text { spelling }\end{array}$ \\
\hline 0396 & Ende alsi hi dan te goede es comen & $\mathrm{k}[\mathrm{o}:] \mathrm{men}$ & $<$ komen> \\
\hline 0397 & So gaettene dan tfolc verdoemen & verd[u:]men & $<$ verdoemen> \\
\hline
\end{tabular}

\begin{tabular}{|c|c|c|c|}
\hline 0428 & Ende sal ten ionxten daghe comen & $\mathrm{k}[\mathrm{o}:] \mathrm{men}$ & $<$ komen $>$ \\
\hline 0429 & Alle menschen doemen & $\mathrm{d}[\mathrm{u}:] \mathrm{men}$ & $<$ doemen $>$ \\
\hline
\end{tabular}

\begin{tabular}{|c|c|c|c|}
\hline 0595 & Si moet al uter herten comen & $\mathrm{k}[\mathrm{o}:] \mathrm{men}$ & $<$ komen $>$ \\
\hline 0596 & Die anders segghen si hen versoemen & vers[u:]men & $<$ vezuimen $>$ \\
\hline
\end{tabular}

In Section 2, we argued that words like doemen $(<\mathrm{PGmc} *$ doma-) have the high back vowel /u:/ in Middle Dutch and versoemen $\left(<\mathrm{PGmc} *^{*}\right.$ üma-) is probably 
unchanged. The three examples in (21) suggest that the long /o:/ in comen could be raised to long /u:/ when the rhyme required it, but this was not possible for the vowel that was the result of monophthongization of $\mathrm{PGmc} * / \mathrm{au} /$.

That words with PGmc */o:/ did not show any variation between $<$ oe $>$ and $<00>$ (see Section 2), suggests to us that the change from PGmc */o:/ to /u:/ was complete when Marshall 29 was written.

Combining the changes reflected in the rhymes so far, we propose the following orthography-pronunciation correspondences and constraints on variation:

(22) $\mathrm{MNL}$ pronunciation of $<_{\mathrm{O}}>,<_{\mathrm{OO}}>,<_{\mathrm{oe}}>$

\begin{tabular}{|c|c|c|c|}
\hline spelling & PGmc & $\begin{array}{l}\text { Middle Dutch } \\
\text { pronunciation }\end{array}$ & other contextual variants \\
\hline$<$ oe $>$ only & */o:/ & $\begin{array}{c}\text { /u:/ in closed and open } \\
\text { syllables }\end{array}$ & $/ \mathrm{u}: /$ can be fronted to $/ \mathrm{y}: /$ \\
\hline$<0>$ only & $* / \mathrm{u} /$ & $\begin{array}{l}\text { /っ/ in closed syllables } \\
\text { /っ:/ in open syllables }\end{array}$ & $\begin{array}{c}/ \supset: / \text { can be raised to } / \mathrm{u}: / \\
\text { when the rhyme requires } \\
\text { it }\end{array}$ \\
\hline $\begin{array}{c}<\mathrm{oe}>,<\mathrm{oo}>\text { in } \\
\text { closed } \\
\text { syllables } \\
<0>\text { in open } \\
\text { syllables }\end{array}$ & $* / a u /$ & $\begin{array}{c}\text { /о:/ in closed } \\
\text { and open syllables }\end{array}$ & $\begin{array}{l}\text { /o:/ cannot be raised to } \\
\text { /u:/ }\end{array}$ \\
\hline
\end{tabular}

To reiterate, raising of long /o:/ was possible for words spelt with $<_{0}>$ in open syllables, such as comen in a rhyme pair with doemen. However, words that are spelt with $<_{0}>$ that belong to the category discussed in Section 4 never rhyme with words that are spelt $<\mathrm{oe}>$. Thus, not just any long mid vowel could be raised to [u:].

\section{Conclusion}

Numerous phonological processes affected the back rounded vowels as they changed from PGmc to Modern Dutch via MNL. We surveyed these changes by studying one particular MNL manuscript written in verse, scrutinizing the variation, if any, in the vocalic symbols in rhyming pairs. We approached the problem from three angles: (i) examining the variability versus consistency in spelling in the manuscript; (ii) tracing the PGmc sources and investigating whether the descendants rhymed or not; and (iii) comparing the Modern Dutch pronunciation with the MNL words, contrasting those that did or did not rhyme. Both variability as well as consistency in the rhymes helped us to draw a trajectory from PGmc to the Dutch spoken today. We traced each vowel back to PGmc and used comparative evidence from other WGmc languages when we were in doubt regarding the interpretation of certain symbols. A summary of our conclusions is given in (23). 
The main findings based on our manuscript are the following. First, as is frequent in other manuscripts, $<\mathrm{e}>$ was used as a lengthening marker, although as we have seen, it could be used to indicate fronting. Second, the raising of PGmc */o:/ to /u:/ was already complete when the manuscript was written and it seems to have remained unchanged since then. In Section 2, we demonstrated that words with <oe> that developed from PGmc*/o:/ (e.g., boec PGmc *bōk-) always correspond to Modern Dutch /u:/ (or /u/ for some speakers, as in boek 'book', which would indicate shortening at a later period). The fact that the attested spelling for these words in open syllables was always $<$ oe $>$ (indicating length) and never $<_{0}>$ suggests that the change from PGmc */o:/ to /u:/ was complete in the Brabant dialect before the manuscript was composed.

Third, this vowel has another variant; occasionally it is written as $<$ ue $>$ which we argue had a front rounded quality of/y:/. Judging from the occasional spelling $<$ ue $>$, we hypothesize that /u:/ could be palatalized to /y:/ in the context of /i/ or its unstressed form /e/ in the 14th century Brabant dialect. The assumption that <ue $>$ indicates fronting is supported by the fact that this grapheme in other contexts from a different PGmc source has developed as /y:/ in Modern Dutch.

Fourth, PGmc */u:/ was particularly variable. Our claim is that it was palatalized to / $\mathrm{y}: /$ before $/ \mathrm{r}$ / (written as $<\mathrm{u}>$ in open syllables, and $<\mathrm{ue}>$ in closed syllables) and diphthongized to /øy/ in all other contexts, spelt $<\mathrm{u}>$ in open syllables, and $<$ uy $>$ or $<\mathrm{uu}>$. Thus, we conclude that $<\mathrm{uu}>$ and $<\mathrm{uy}>$ represented a sound different from the one written as $<$ ue $>$ (cf. Section 3). Our evidence comes from rhymes; words with $<$ uy $>$ or $<$ uu $>$ never rhyme with words with $\langle\mathrm{u}>$ or $<\mathrm{ue}>$, the difference being maintained in Modern Dutch. MNL $<$ uy $>$ and $<$ uu $>$ was most probably close to a centralized vowel /øy/, which further lowered to present day /œy/. And $<\mathrm{u}>$ or $<\mathrm{ue}>$ before /r/ was probably /y:/.

Fifth, the vowel which arose from PGmc $/ *$ au/ could be written as $<$ oe $>$ or $<$ oo $>$ in closed syllables or $\left.<_{0}\right\rangle$ in open syllables. The differences in the graphemes are representative of two hands (see (17). The vowel in question was most probably pronounced as an open-mid back long vowel.

Sixth, the quality of the vowel developed from PGmc */au/ was distinct from the lowered vowel from $\mathrm{PGmc} * / \mathrm{u} /$ since these words never rhyme. Further support comes from the fact that it is possible to raise $/ \mathrm{o}: /(<\mathrm{PGmc} * / \mathrm{u} /)$ to $/ \mathrm{u}: /$ when rhyme requires this, but a similar type of raising is not evident in any instances of /o: $<$ PGmc */au/ (Section 5).

Finally, it is unclear from the round vowels whether open syllable lengthening had occurred or not. All descendants from $\mathrm{PGmc} * / \mathrm{u} /$ were written as $<0>$ without any lengthening vowel. However, in (20) we saw that in a few words $<00>$ was used in closed syllables signifying that this vowel was lengthened. More interesting is the fact that this vowel never rhymed with the vowel inherited from PGmc */au/ which was clearly long in MNL. Whether this was because the MNL version of $\mathrm{PGmc} * / \mathrm{u} /$ was always short or whether the quality was different, or both, remains unclear. There is more conclusive evidence of lengthening from the unrounded vowels where original short vowels rhyme with original long vowels (e.g., <sake > from PGmc */a/ rhymes with < sprake> from PGmc */e:/, Lahiri \& Sytsema (2013)). Thus, we have assumed that OSL has taken place but the PGmc */u/ in open syllables is MNL / $/$ / and therefore never rhymes with /o:/ from PGmc */au/. 
A complete summary of our findings is given in (23).

(23)

PGmc vowels and their MNL counterparts in Marshall 29

\begin{tabular}{|c|c|c|c|c|}
\hline PGmc & $\begin{array}{l}\text { Marshall } 29 \\
\text { spelling }\end{array}$ & $\begin{array}{l}\text { MNL } \\
\text { pronunciation }\end{array}$ & $\begin{array}{l}\text { Dutch } \\
\text { spelling }\end{array}$ & Dutch \\
\hline \multirow[b]{2}{*}{ */o:/ } & $<$ oe $>$ only & /u:/ & $<$ oe $>$ & {$[\mathrm{u}:] /[\mathrm{u}]$} \\
\hline & $<$ ue $>$ & $\begin{array}{l}/ y: /(</ \varnothing: /) \text { in the } \\
\text { context of /i/ }\end{array}$ & & $\begin{array}{l}\text { obsolete in } \\
\text { Modern Dutch; } \\
\text { occurs in some } \\
\text { dialects }\end{array}$ \\
\hline \multirow[b]{2}{*}{ */u:/ } & $\begin{array}{l}\text { before }<\mathrm{r}> \\
<\mathrm{u}>_{\text {open syll }} \\
<\mathrm{ue}>\end{array}$ & /y:/ before /r/ & $\begin{array}{l}\text { before }<\mathrm{r}> \\
<\mathrm{U}\rangle_{\text {open syll }} \\
\langle\mathrm{uu}\rangle_{\text {closed syll }}\end{array}$ & [y] before /r/ \\
\hline & $\begin{array}{l}\text { in all other } \\
\text { contexts } \\
<\mathrm{u}>_{\text {open syll }} \\
<\mathrm{uy}>,<\mathrm{uu}>\end{array}$ & /фy/ & $<$ ui $>$ & [œy] \\
\hline$* / \mathrm{u} /$ & $<0>$ & $\begin{array}{l}\text { /Ј:/ open syll } \\
\text { /Ј/ closed syll } \\
\text { (/っ:/ can be } \\
\text { raised to /u:/ } \\
\text { when rhyme } \\
\text { requires it) }\end{array}$ & $\begin{array}{l}<\mathrm{O}>_{\text {open syll }} \\
<\mathrm{O}>_{\text {closed syll }}\end{array}$ & $\begin{array}{l}{[\mathrm{o}:]_{\text {open syll }}} \\
{[\mathrm{o}]_{\text {closed syll }}}\end{array}$ \\
\hline$* / a u /$ & $\begin{array}{l}<0>_{\text {open syll }} \\
<\mathrm{oe}>\text { closed syll } \\
\text { early chapters } \\
<\mathrm{oO}>_{\text {closed syll }} \\
\text { later chapters }\end{array}$ & $\begin{array}{l}\text { /o:/ (cannot be } \\
\text { raised to } / \mathrm{u}: /)\end{array}$ & $\begin{array}{l}<0>_{\text {open syll }} \\
<00>_{\text {closed }} \\
\text { syll }\end{array}$ & [o:] \\
\hline
\end{tabular}

Our results are generally compatible with the philological literature exemplified in van Bree (1987) and van Loey (1968) and Van Gestel et al. (1992). ${ }^{25}$ Nevertheless, the careful study of a single manuscript raised new issues. The written symbol $<_{0}>$ used in the manuscript descended from PGmc */u/ or */au/, but only a careful examination of the rhyme made it clear that the descendants of these vowels must have had a different vowel quality, /o:/ and /o:/ respectively. A later change neutralized the contrast such that the vowel is now always /o:/ in Modern Dutch. The use of $<\mathrm{e}>$ as a second member as in $<\mathrm{oe}>$ appeared variable at first glance but was seen to be systematic when using comparative evidence. When a word with $<\mathrm{oe}>$ descended from PGmc */o:/ it was always a raised vowel. However, the $<\mathrm{e}>$ was used to indicate fronting when written as $<\mathrm{ue}>$, and a length marker elsewhere, as we see in the use of $<0 e>$ in the first half of the manuscript for the vowel descended from */au/.

Rhyming verse has provided evidence towards establishing the phonology of round vowels in Middle Dutch. It has been possible to trace the development from Proto Germanic to Middle Dutch based on what did rhyme and what did not rhyme. Thus, lack of rhyming for particular vowels was very informative. We could also reliably conclude which vowels have undergone change from Middle Dutch to modern times.

\footnotetext{
${ }^{25}$ In addition, we have drawn on Antonsen (1972), Goossens (1962), Heeroma (1965) and Grootaers (1959).
} 
Acknowledgments Aditi Lahiri and Johanneke Sytsema's research was partially supported by a British Academy grant (No. SG-54423) and by an AHRC Ref: AH/I003754/1 research grant entitled 'Word and Sentence Phonology in Middle Dutch'. A first version of this paper was presented at the 'Germanic Sandwich' conference in Oldenburg in September 2010. This paper has benefitted greatly from the comments by the reviewers.

\section{Appendix}

Table 1 Words with PGmc */au/ spelt with $<0>,<00>,<0 e>$ in Marshall 29

\begin{tabular}{|c|c|c|c|c|}
\hline PGmc & $\begin{array}{l}\text { Open syllables Books I, II, } \\
\text { III \& IV }\end{array}$ & $\begin{array}{l}\text { Closed syllables } \\
<\text { oe > Book I, II, III } \\
\text { (up until line 1113) }\end{array}$ & $\begin{array}{l}\text { Closed syllables with } \\
<\text { oe }><\text { oo }>\text { Book III } \\
\text { (from line 1114) \& } \\
\text { Book IV }\end{array}$ & Gloss \\
\hline *augan & $\begin{array}{l}\text { oghen }(0345) \text { oghen }(1549) \\
\text { doghen }(\mathrm{e})(0860,1820)\end{array}$ & & & $\begin{array}{l}\text { 'eyes' } \\
\text { 'the eyes' }\end{array}$ \\
\hline *auke & & $\begin{array}{l}\text { oec }(34 \times)(27 \times \text { up } \\
\quad \text { until } 1113)\end{array}$ & $\begin{array}{l}\text { ooc }(1859) \\
\text { oec }(7 \times \text { after } 1114)\end{array}$ & ‘also’ \\
\hline *blauta & & $\begin{array}{l}\text { bloet }(0086,1106) \\
\text { bloetheyt }(0123)\end{array}$ & $\begin{array}{l}\text { bloet (2052) } \\
\text { bloetheit }(1763)\end{array}$ & $\begin{array}{l}\text { 'bare' } \\
\text { 'naked','nakedness' }\end{array}$ \\
\hline Lat. caupō & voercopen (0399) & & voorcoop (1342) & 'to corner the market' \\
\hline *dauda & doden $(1316,1332)$ & $\begin{array}{l}\text { doet }(0053,0501, \\
0698,0709,0798, \\
0811,0861) \\
\text { ghedoedt }(0742)\end{array}$ & $\begin{array}{l}\text { doot }(1240,1638 \\
\quad 1643,1649,1739 \\
1748)\end{array}$ & 'dead', 'death' \\
\hline *drauman & drome (1214) & $\begin{array}{l}\text { droem }(0974,1029) \\
\text { droemde }(0973,0976)\end{array}$ & & $\begin{array}{l}\text { 'dream'; } \\
\text { 'dreamt' }\end{array}$ \\
\hline * grauta & $\begin{array}{l}\text { groete }(1299) \\
\operatorname{grote}(n / r)(20 \times)\end{array}$ & groet $(16 \times)$ & $\begin{array}{l}\text { groet }(2 \times) \\
\text { groot }(8 \times)\end{array}$ & 'big; great' \\
\hline \multirow[t]{2}{*}{ *haub-id- } & & $\begin{array}{l}\text { hoeft }(0157,0500, \\
\quad 0523)\end{array}$ & hooft (1784) & 'head' \\
\hline & & & hoeftsonden (1916) & 'cardinal sins' \\
\hline *hauha & $\begin{array}{l}\text { hogher }(0225,0556,1691) \\
\text { hoghen }(0288,0828) \\
\text { hoghe }(1695,1898,1913 \text {, } \\
\quad 1965) \\
\text { hoeghe }(1824)\end{array}$ & & & $\begin{array}{l}\text { 'higher' } \\
\text { 'high' }\end{array}$ \\
\hline *hlaupan & lopen (0398) & loept (0380) & loop (1343) & 'go, walk' \\
\hline- & $\begin{array}{c}\text { ghelouen }(0446,0471, \\
1438,1444,2074)\end{array}$ & $\begin{array}{l}\text { gheloeft }(0411 \text {, } \\
\text { 0524) }\end{array}$ & gheloeft $(1247,2064)$ & 'believe(d)' \\
\hline *naudi & node $(0061)$ & noet (0794) & noot $(1266,1741)$ & 'need' \\
\hline *rauda & & roet $(0992,1009)$ & $\operatorname{root}(1265,1735)$ & 'red' \\
\hline *skauni & $\begin{array}{l}\text { scone }(0226,0241,0326 \\
0327,0561,0934,0948 \\
1016,1025,1101,1310 \\
1720,1727)\end{array}$ & $\begin{array}{l}\text { scoenre }(0234) \\
\text { scoenheden } \\
(0238) \\
\text { tscoenste }(0369)\end{array}$ & & $\begin{array}{l}\text { '(more) beautiful' } \\
\text { 'beauties' } \\
\text { 'the most beautiful' }\end{array}$ \\
\hline *traustan & & troesten $(0803)$ & & 'to comfort' \\
\hline
\end{tabular}

The spelling < groet $>$ is found in lines 0052, 0057, 0065, 0085, 0379, 0699, 0708, 0777, 0797, 0826, 0840, $0843,0961,0968,1105,1192,1239,1571$; <groot $>$ is exclusively attested in the second half of the ms. in lines 1333, 1378, 1397, 1439, 1474, 1737, 1949, 2030.

In open syllables, we find the spelling <grote> 'big one' (lines 0045, 0053, 0940, 0947, 1232, 1236, 1776, 1941, 1951); <groter> 'bigger' (lines 0907, 0963, 0983, 1063, 1312, 1824) and <groten> 'big; large' (lines $0765,1335,1383,1632,1638)$. 


\section{References}

Amos, A.C., Angus, C., Antonette, D.H. 1986. Dictionary of Old English. Toronto: Pontifical Institute of Mediaeval Studies.

Antonsen, E.H. 1972. The proto-Germanic syllabics (vowels). In Towards a grammar of proto-Germanic, ed. Frans van Coetsem and Herbert L. Kufner, 117-140. Tübingen: Max Niemeyer Verlag.

Bree, C. van. 1977. Leerboek voor de historische grammatica van het Nederlands. Klank-en vormleer. Met een beknopte grammatica van het Gotisch. Groningen: Wolters-Noordhoff.

Bree, C. van. 1987. Historische grammatica van het Nederlands. Dordrecht: Foris Publications.

Berg, E. van den. 1986. Over het lokaliseren van Middelnederlandse rijmteksten. Verslagen en mededelingen van de Koninklijke Academie voor Nederlandse taal- en letterkunde (nieuwe reeks): 305-322.

Berg, E. van den and Amand Berteloot. 1991. Taalgeografische variabelen in middelnederlandse rijmen. Verslagen en mededelingen van de Koninklijke Academie voor Nederlandse taal- en letterkunde (nieuwe reeks): $238-273$.

Berg, E. van den and Amand Berteloot. 1994. Van dichter tot kopiist Een dialectgeografisch onderzoek. Tijdschrift voor Nederlandse Taal- en Letterkunde 110: 34-54.

Besamusca, B., Sleiderink, R., and G. Warnar. 2009. Ter inleiding. In De boeken van Velthem. Auteur, oeuvre en overlevering, Middeleeuwse studies en bronnen 119, 7-30. eds. B. Besamusca, R. Sleiderink and G. Warnar. Hilversum: Verloren.

Buccini, A.F. 2010. Between pre-German and pre-English: the origin of Dutch. Journal of Germanic Linguistics 22: 301-314.

Deschamps, J. 1972. Middelnederlandse handschriften uit europese en amerikaanse bibliotheken. Tweede herziene druk (second revised version). Leiden: Brill.

Fikkert, P. 2000. Prosodic variation in 'Lutgart'. In Analogy, levelling, markedness. Principles of change in phonology and morphology. Trends in linguistics. Studies and monographs 127, 301-332. ed. A. Lahiri. Berlin/New York: Mouton de Gruyter.

Franck, J. 1910. Mittelniederländische grammatik : mit lesestücken und glossar. Zweite, neubearbeitete aufl. Leipzig: Herm. Tauchnitz.

Gestel, F. van, Twilhaar, J.N., Rinkel, T., and F. Weerman. 1992. Oude zinnen. Grammaticale analyse van het Nederlands tussen 1200-1700. Leiden \& Antwerpen: Nijhoff.

Goossens, J. 1962. Die gerundeten palatalvokale im niederländischen sprachraum. Zeitschrift für Mundartforschung 29: 313-328.

Grootaers, L. 1959. Inleiding tot de taalkunde en tot de geschiedenis van het Nederlands. Leuven: Vlaamse Drukkerij \& Wolters.

Gussenhoven, C. 1999. Dutch. In Handbook of the International Phonetic Association, 74-77. Cambridge: CUP.

Heeroma, K. 1965. De herkomst van het Nederlandse vocalisme. Taal en Tongval 17: 162-180.

Kestemont, M. 2013. Het gewicht van de auteur; Stylometrische auteursherkenning in de Middelnederlandse literatuur. Gent: KANTL.

Kienhorst, H. 2005. Hoe moet zo'n boek genoemd worden? Belgisch Tijdschrift voor Filologie en Geschiedenis 83: 785-817.

Kloeke, G.G. 1927. De hollandsche expansie in de zestiende en zeventiende eeuw en haar weerspiegeling in de hedendaagsche nederlandse dialecten: proeve eener historisch-dialect-geographische synthese. Gravenhage: Martinus Nijhoff.

Lahiri, A., and J. Sytsema. 2013. Open syllable lengthening and iambic-trochaic rhythm in Middle Dutch. Talk presented at the Manchester Phonology Meeting, MfM21.

Lahiri, A., and B.E. Dresher. 1999. Open syllable lengthening in West Germanic. Language 75: 678-719.

Loey, A. van. 1937. Bijdrage tot de kennis van het Zuidwestbrabantsch in de 13de en 14de eeuw: Fonologie. Tongeren: Drukkerij G. Michiels-Broeders.

Loey, A. van. 1968. Middelnederlandse spraakkunst, I Vormleer, 9e druk 1980, II Klankleer, 8e druk 1980. Groningen: Tjeenk Willink \& Wolters/Noordhoff.

Meer, M.J. van der. 1927. Historische grammatik der Niederländischen sprache. Heidelberg: Carl Winter's Universitätsbuchhandlung.

Oxford English dictionary, 2nd edition. 2009. Oxford: Oxford University Press.

Philippa, M., F. Debrabandere, A. Quack, T. Schoonheim, and N. van der Sijs. 2003-2009. Etymologisch woordenboek van het Nederlands. Amsterdam: Amsterdam University Press.

Postma, G.J., and P. van. Reenen. 2009. De wisselwerking tussen spontane palatalisatie, umlaut en genus. Taal en tongval. Themanummer: 18: 109-152. 
Reenen, P. van. 2006a. In Holland staat een 'Huis', Kloekes expansie-theorie met speciale aandacht voor de dialecten van Overijssel. Amsterdam Münster: Stichting Neerlandistiek VU \& Nodus Publikationen.

Reenen, P. van. 2006b. 'Goed' en 'uit' in de Nederlandse dialecten. In In Holland staat een 'Huis', Kloekes expansie-theorie met speciale aandacht voor de dialecten van Overijssel, 69-88. ed. P.van Reenen. Amsterdam Münster : Stichting Neerlandistiek VU \& Nodus Publikationen.

Reenen, P. van and A. Wijnands. 1993. Early diphthongizations of palatalized West Germanic [u:] : the spelling uy in Middle Dutch. In Historical linguistics 1989: Papers from the 9th International Conference on Historical Linguistics, Rutgers University, 14-18 August 1989, 389-415. ed. by Henk Aertsen, Robert J. Jeffers.

Schönfeld, M. 1947. Schönfeld's Historische grammatica van het Nederlands : klankleer, vormleer, woordvorming, 8e druk 1970. Zutphen : W. J. Thieme.

Skeat, W.W. 1882-1884. An etymological dictionary of the English language (OEED). Revised ed. 1953. Oxford : Clarendon Press.

Trommelen, M. 1983. The syllable in Dutch. Dordrecht: Foris Publications.

Twaddell, W.F. 1938. A note on Old High German umlaut. Monatshefte für deutschen Unterricht 30: 177181.

Verwijs, E., and J. Verdam. 1885. Middelnederlandsch Woordenboek (MNW). 's-Gravenhage: M.Nijhoff.

Zonneveld, W. 1992. Van Afflighem en Chaucer: Het leven van Sinte Lutgart als jambisch gedicht. RuyghBewerb XVII, University of Utrecht. 